\title{
Efektivitas Pembelajaran Matematika melalui Metode Penemuan Terbimbing Setting Kooperatif
}

\author{
Nur Qalbi Tayibu' ${ }^{1}$ dan Andi Nurul Faizah ${ }^{2 *}$ \\ Program Studi Teknik Elektro, Institut Sains dan Teknologi Pembangunan Indonesia \\ (IST-PI) Makassar \\ Jalan Inspeksi Kanal Aroepala-Gowa, Kota Makassar, Sulawesi Selatan, Indonesia \\ 1nurqalbitayibu@istpi.ac.id \\ Program Studi Sistem Informasi, Sekolah Tinggi Bina Adinata \\ Jalan Srikaya No.8, Bulukumba, Sulawesi Selatan, Indonesia \\ $2^{*}$ nf051990@gmail.com
}

Artikel diterima: 13-02-2020, direvisi: 27-01-2021, diterbitkan: 31-01-2021

\begin{abstract}
Abstrak
Berbagai masalah dihadapi siswa dalam proses pembelajaran sehingga hasil belajar siswa rendah. Minat dan motivasi belajar siswa juga kurang. Diperlukan pembelajaran yang mengkondisikan siswa agar aktif belajar. Dengan penggunaan metode penemuan terbimbing setting kooperatif, siswa diharapkan menemukan sendiri pola atau struktur matematika melalui proses pengalaman belajar. Penelitian ini bertujuan mengetahui apakah metode penemuan terbimbing setting kooperatif efektif diterapkan pada pembelajaran matematika. Penelitian eksperimen ini dilakukan dengan sampel sebanyak 50 Siswa kelas VIII SMP Negeri 21 Makassar. Pengumpulan data menggunakan tes hasil belajar, lembar observasi, dan angket respon siswa. Analisis yang digunakan yaitu analisis deskriptif dan inferensial. Hasil analisis data yaitu metode penemuan terbimbing setting kooperatif lebih efektif dibandingkan metode konvensional, dapat dilihat dari hasil yang diperoleh kelas eksperimen lebih baik dibandingkan kelas kontrol pada tes hasil belajar, angket dan respon siswa. Metode penemuan terbimbing dengan menggunakan setting kooperatif sangat cocok digunakan pada penelitian pembelajaran matematika karena dapat melihat sejauh mana siswa aktif belajar, minat, motivasi dan hasil belajar siswa.

Kata Kunci: Kooperatif, Metode Penemuan Terbimbing, Pembelajaran Matematika
\end{abstract}

\section{The Effectiveness of Learning Mathematics through the Guided Discovery Method of Cooperative Settings}

\begin{abstract}
Various problems faced by students in the learning process so that the student's learning outcomes are low. Interest and motivation of the students in the learning are also lacking. Learning is required who students condition to be active in the study. With the use of the guided discovery method of settings cooperative, students are expected to discover their mathematical patterns or structures through the learning experience process. This study aims to find out that the method of discovery guided cooperative settings are effectively applied to student math learning. This experimental research was conducted with sample as many as 50 students of SMP Negeri 21 Makassar. Data collection using test results of learning, observation sheets, and student questionnaire responses. The analysis used is descriptive and inferential. The results of the data analysis show that the guided discovery method of a cooperative setting is more effective than conventional methods, can be seen from the results obtained by the experimental class better than the control class on the test. The guided discovery method by using cooperative settings is very suitable in use of mathematics learning research, because we can see the extent to which students are actively learning, the extent of interest, motivation and learning outcomes of students.

Keywords: Cooperative, Guided Discovery Method, Mathematics Learning
\end{abstract}




\section{Pendahuluan}

Misi pendidikan adalah upaya dalam mencerdaskan anak-anak bangsa dan mengembangkan potensi mereka seutuhnya (Suharyono \& Rosnawati, 2020). Pendidikan yang berpusat pada kualitas sangat dibutuhkan dalam dunia pendidikan dengan tidak lagi melihat tingkat pendidikan maupun orangnya (Nurmawanti \& Sulandra, 2020). Semua unsur pendidikan yang terlibat dituntut secara bersama-sama membangun pendidikan yang berkualitas (Afriansyah, 2014). Hal ini sejalan dengan pendapat dari (Purwananti, 2016) bahwa pendidikan merupakan tonggak utama dalam menciptakan peradaban bangsa. Dengan adanya kualitas pendidikan yang baik maka akan meningkat juga kualitas sumber daya manusianya.

Matematika merupakan salah satu pelajaran yang bersifat umum dan menjadi dasar dalam pengembangan IPTEK (Puspitasari, 2018). Menurut Skemp (Sholihah \& Mahmudi, 2015) bahwa matematika metode yang sangat baik untuk memenuhi kebutuhan manusia dan sebagai alat bantu dalam pengembangan ilmu pengetahuan. Siswa yang belajar matematika diharapkan mampu mengembangkan kemampuan yang ada dalam dirinya sehingga dapat mempersiapkan diri dalam menyambut perkembangan zaman (Siregar, 2016). Hal ini dapat dicapai jika siswa mampu membentuk sendiri pengetahuannya melalui pengalaman-pengalaman belajar dan latihan yang terstruktur di kelas maupun di lingkungan sekitar dan dapat tercapai jika guru mampu mendesain pembelajaran yang dapat membangkitkan minat dan motivasi sehingga akan berpengaruh dalam keaktifan belajar di kelas (Afriansyah, dkk., 2020). Menurut (Idzhar, 2016) bahwa peran guru sangat substansial dalam proses belajar mengajar. Peran guru di kelas tidak hanya sebagai pengajar akan tetapi juga sebagai manager kelas, supervisor, motivator, konsuler, dan motivator (Latifah \& Madio, 2014). Siswa yang memiliki minat maupun motivasi yang rendah akan sangat berpengaruh terhadap capaian belajarnya (Siregar \& Sari, 2020). $\mathrm{Hal}$ ini sependapat dengan penelitian yang dilakukan oleh (Warti, 2018) mengungkapkan bahwa motivasi efektif dalam meningkatkan hasil belajar siswa.

Namun kenyataan yang ada di SMP Negeri 21 Makassar masih ditemui beberapa persoalan belajar peserta didik mulai dari hasil belajar siswa yang rendah sampai pada minat dan motivasi belajar siswa yang kurang. Hasil belajar rendah dapat dilihat dari nilai yang diperoleh siswa tidak mencapai standar ketuntasan yang telah ditetapkan, sedangkan minat siswa yang rendah dapat terlihat dari tingkat keterlibatan dan antusiasme siswa dalam mengikuti pelajaran matematika sangat rendah. Minat dan motivasi yang rendah ini disebabkan tidak adanya keaktifan siswa di kelas. Siswa hanya menerima materi yang diberikan dan tidak memproses secara optimal pengetahuan yang diberikan oleh guru.

Dari pemaparan kenyataan yang ada, perlu adanya pembelajaran yang membuat siswa aktif dalam belajar matematika. Menurut Henningsen dan Stein (Ariandi, 2016) untuk mengembangkan potensi 
matematis siswa, maka lingkungan belajar harus didesain sebaik mungkin agar siswa dapat terlibat secara aktif dalam proses belajar matematika yang bermanfaat. Siswa tidak hanya menerima pengetahuan yang diberikan oleh guru akan tetapi mampu memproses pengetahuan yang diperoleh (Pitriani \& Afriansyah, 2016).

Metode konvensional yang ditandai dengan ceramah hanya berfokus pada buku referensi sehingga bersifat monoton (Widiawati \& Sofyan, 2013). Hal ini menyebabkan siswa kurang aktif dalam proses belajar yang akhirnya dapat berpengaruh terhadap hasil belajar. Hal ini sejalan dengan pendapat (Karlina \& Rasam, 2020) bahwa guru menggunakan metode pembelajaran yang monoton maka siswa akan cepat bosan, kurang antusias dengan materi yang diajarkan bahkan mereka akan menanggap mata pelajarannya terkesan sulit dipahami. Oleh karena itu, guru dituntut untuk selalu berkreasi di kelas dengan menciptakan suasana belajar yang menyenangkan sehingga siswa dapat menyerap pelajaran dengan baik.

Salah satu metode pembelajaran yang akan membuat siswa aktif belajar dalam kelas yaitu metode penemuan terbimbing dengan setting kooperatif, siswa diharapkan dapat memperoleh sendiri bentuk atau desain matematika melalui proses belajar. Menurut Muhsetyo (Alam \& Razak, 2018) bahwa penemuan terbimbing adalah kegiatan pembelajaran yang dilakukan pleh siswa untuk mencari sendiri pengetahuan dengan menggunakan langkah-langkah yang terstruktur. Menurut Khasnit dan Manjunat (Rochani, 2016), penemuan terbimbing merupakan kombinasi dari strategi belajar mandiri dan kelompok. Sedangkan metode pembelajaran kooperatif menurut Slavin (Gillies, 2016) metode pembelajaran kooperatif dibandingkan dengan pembelajaran individualistik memiliki pengaruh yang sangat kuat terhadap berbagai variabel dependen seperti prestasi belajar, motivasi dan pengembangan diri.

Dalam metode penemuan terbimbing setting kooperatif, siswa dituntut lebih aktif dalam belajar. Menurut (Wibowo, 2016) keaktifan siswa dalam proses pembelajaran akan menciptakan pembelajaran berjalan sesuai dengan rencanayang telah disusun oleh guru, aktifitas siswa dapat berupa aktifitas terhadap diri sendiri ataupun dalam kelompoknya. Winarti (Putri, Amelia, \& Gusmania, 2019) berpendapat bahwa dengan adanya keaktifan siswa akan membuat suasana kelas yang kondusif.

Siswa dijadikan sebagai pusat belajar dan guru hanya sebagai penghubung yang memberikan penjelasan seadanya sebagai pengantar bagi siswa dalam proses belajar. Dengan adanya keaktifan siswa belajar di kelas, hal itu akan mampu mendongkrak hasil belajarnya. Menurut hasil penelitian yang dilakukan oleh (Puspitaningdyah \& Purwanti, 2018), keaktifan belajar siswa berpengaruh positif terhadap hasil belajar siswa.

Penelitian yang dilakukan mengenai metode penemuan setting kooperatif telah banyak diteliti diantaranya metode Penemun terbimbing yang disandingkan 
dengan metode pembelajaran kooperatif diteliti oleh (Sejati \& Widjajanti, 2019) diperoleh hasil bahwa dengan model pembelajaran kooperatif dengan tipe STAD dan TAl dalam pendekatan penemuan terbimbing efektif meningkatkan prestasi belajar, kepercayaan diri, dan kemampuan berpikir kritis siswa. Penelitian serupa juga dilakukan oleh (Tahir \& Kurniawan, 2020) yang menemukan bahwa mahasiswa yang diajar menggunakan metode penemuan terbimbing memperoleh nilai rata-rata kemampuan pemecahan masalah lebih tinggi dibandingkan dengan menggunakan metode konvensional. (Riyadi, Mulyono, \& Purwasi, 2018) juga memperoleh hasil yang sama bahwa tercapainya ketuntasan hasil belajar matematika siswa setelah diterapkan metode pembelajaran discovery learning (metode penemuan). Hal ini juga didukung dari hasil penelitian yang dilakukan oleh (Saridewi, Suryadi, \& Hikmah, 2017) yang menunjukkan hasil bahwa discovery learning (pembelajaran berbasis penemuan) dapat memberi pengaruh positif terhadap peningkatan nilai motivasi dan hasil belajar siswa. (Jumhariyani, 2016) juga memperoleh dalam penelitiannya bahwa emampuan siswa dalam belajar matematika lebih tinggi dengan menggunakan metode penemuan terbimbing dibandingkan dengan metode ekspositori.

Berdasarkan dari uraian di atas maka dirumuskan tujuan penelitan ini adalah untuk mengetahui keefektifan metode penemuan terbimbing setting kooperatif jika diterapkan pada pembelajaran matematika siswa sehingga dapat mendorong keaktifan siswa agar hasil belajar siswa mencapai standar ketuntasan yang telah ditetapkan.

\section{Metode}

Penelitian ini termasuk metode penelitian eksperimen semu dengan dua kelompok siswa dengan tindakan yang berbeda dalam pembelajaran yaitu kelompok eksperimen dan kelompok kontrol. Desain pada penelitian ini adalah jenis Posttest only control group design (Khotimah, Kuswandi, \& Sulthoni, 2019). Desain ini digunakan karena penelitian ini melibatkan dua kelas, yaitu kelas eksperimen dan kelas kontrol yang dipilih dan ditempatkan secara random.

Populasi dalam penelitian ini adalah seluruh siswa kelas VIII SMP Negeri 21 Makassar yang terdiri dari 9 kelas. Sampel dalam penelitian ini terdiri dari dua kelas yang dipilih dengan menggunakan teknik "Cluster Random Sampling" atau "sampel acak kelompok".

Desain pada penelitian ini adalah jenis Posttest only control group design. Desain ini digunakan karena penelitian ini melibatkan dua kelas, yaitu kelas eksperimen dan kelas kontrol yang dipilih dan ditempatkan secara random. Kelas eksperimen diberikan perlakuan dan kelas kontrol tidak diberikan perlakuan. Instrumen yang digunakan yaitu lembar observasi siswa untuk mengetahui aktivitas siswa selama proses pembelajaran 
berlangsung sedangkan guru untuk mengetahui kemampuan guru mengelolah pembelajaran, angket untuk respon siswa terhadap pembelajaran yang telah dilakukan dan tes hasil belajar untuk mengetahui hasil belajar siswa.

Teknik pengumpulan data dalam penelitian ini adalah (1) Data tentang respon siswa dapat dilihat dari angket yang diberikan pada siswa dan dari lembar observasi siswa yang digunakan untuk mengamati aktivitas siswa selama proses pembelajaran, (2) data tentang hasil belajar siswa diperoleh dengan memberikan tes di akhir perlakuan (posttest). (3) data tentang tingkat keberhasilan guru di kelas dapat dperoleh dari lembar observasi guru.

Teknik analisis data yang digunakan untuk menganalisis data yang diperoleh adalah dengan menggunakan analisis statistik deskriptif dan analisis statistik inferensial. Statsitik deskriptif digunakan untuk menganalisis hasil belajar yang meliputi nialai tertinggi, terendah, rata-rata dan standar deviasi. Kriteria yang digunakan untuk menentukan kategori hasil belajar dalam penelitian ini adalah dengan menggunakan skala lima yang disusun oleh Departemen Pendidikan Nasional. Kriteria Ketuntasan Minimal belajar siswa jika memenuhi nilai 75 yang telah ditetapkan oleh sekolah.

Analisis statistika inferensial yang digunakan untuk menguji hipotesis penelitian dengan menggunakan uji-t. Namun sebelum dilakukan pengujian hipotesis, terlebih dahulu dilakukan uji normalitas dan uji homogenitas

\section{Hasil dan Pembahasan}

\section{A. Hasil Penelitian}

Gambaran hasil analisis deskriptif kelas eksperimen yang diajar menggunakan metode penemuan terbimbing setting kooperatif disajikan pada tabel 1.

Tabel 1.

Deskripsi Skor Hasil Belajar

\begin{tabular}{|llc|}
\hline No & \multicolumn{1}{c}{ Statistik } & Nilai Statistik \\
\hline 1 & Subjek & 25 \\
\hline 2 & Skor ideal & 100 \\
\hline 3 & Skor maksimum & 95 \\
\hline 4 & Skor minimum & 50 \\
\hline 5 & Rata-Rata & 78
\end{tabular}

Pada tabel 1, dapat dilihat bahwa skor maksimum yang diperoleh siswa yaitu 95 dari skor ideal 100 dengan nilai rata-rata 78.

Tabel 2.

Distribusi dan Persentase Skor Hasil Belajar Kelas Eksperimen

\begin{tabular}{|cccc|}
\hline Skor & Kategori & Frek. & $\%$ \\
\hline $0-54$ & S.rendah & 1 & 4 \\
\hline $55-64$ & Rendah & 4 & 16 \\
\hline $65-79$ & Sedang & 11 & 44 \\
\hline $80-89$ & Tinggi & 7 & 28 \\
\hline $90-100$ & S. Tinggi & 2 & 8 \\
\hline
\end{tabular}

Dari data pada Tabel 2 dapat dilihat bahwa persentase hasil belajar kelas eksperimen berada pada kategori sedang. Selain dikategorikan berdasarkan skala lima yang ditetapkan oleh Depdiknas, hasil belajar juga dikategorikan menurut KKM yang dipakai di SMP Negeri 21 Makassar dapat dilihat pada tabel 3 . 
Tabel 3.

Distribusi Frekuensi Ketuntasan Belajar Siswa pada Kelas Eksperimen

\begin{tabular}{cccc}
\hline Skor & Frek. & $\%$ & Kategori \\
\hline $0-74$ & 5 & 20,00 & T. tuntas \\
\hline $75-100$ & 20 & 80,00 & Tuntas \\
\hline
\end{tabular}

Dari tabel 3 dapat dilihat bahwa untuk siswa yang memperoleh nilai tuntas sebanyak 20 orang dengan persentase sebesar 80,00\%, sedangkan siswa yang memperoleh nilai tidak tuntas sebesar $20,00 \%$.

Adapun gambaran hasil belajar matematika yang diajar dengan menggunakan metode konvensional dapat dilihat Tabel 4, 5, dan 6.

Tabel 4.

Deskripsi Skor Hasil Belajar

\begin{tabular}{|llc|}
\hline No & \multicolumn{1}{c}{ Statistik } & Nilai Statistik \\
\hline 1 & Subjek & 25 \\
\hline 2 & Skor ideal & 100 \\
\hline 3 & Skor maksimum & 95 \\
\hline 4 & Skor minimum & 45 \\
\hline 5 & Rata-Rata & 68,44 \\
\hline
\end{tabular}

Pada tabel 4, dapat dilihat bahwa skor maksimum yang diperoleh siswa yaitu 95 dari skor ideal 100 dengan nilai rata-rata 68, 44 lebih rendah dibandingkan dengan metode penemuan terbimbing setting kooperatif.

Tabel 5.

Distribusi dan Persentase Skor Hasil Belajar Kelas Konvensional

\begin{tabular}{|cccc|}
\hline Skor & Kategori & Frek. & $\%$ \\
\hline $0-54$ & S.rendah & 1 & 4 \\
\hline $55-64$ & Rendah & 7 & 8 \\
\hline $65-79$ & Sedang & 13 & 52 \\
\hline $80-89$ & Tinggi & 2 & 8 \\
\hline $90-100$ & S. Tinggi & 2 & 8
\end{tabular}

Dari hasil analisis pada Tabel 5, dapat disimpulkan bahwa tingkat hasil belajar matematika untuk siswa dengan menggunakan metode konvensional tergolong sedang.

Tabel 6.

Distribusi Frekuensi Ketuntasan Belajar Siswa pada Kelas Konvensional

\begin{tabular}{cccc}
\hline Skor & Frek. & $\%$ & Kategori \\
\hline $0-74$ & 8 & 32,00 & T. tuntas \\
\hline $75-100$ & 17 & 68,00 & Tuntas \\
\hline
\end{tabular}

Dari tabel 6 dapat dilihat bahwa untuk siswa yang memperoleh nilai tuntas sebanyak 17 orang dengan persentase sebesar 68,00\% sedangkan siswa yamg memperoleh nilai tidak tuntas sebanyak 8 orang dengan persentase sebesar $32,00 \%$.

Sedangkan untuk analisis inferensial dapat disajikan sebagai berikut:

1) Uji Normalitas

Hasil perhitungan yang diperoleh untuk kelas Eksperimen nilai $p$-value > yaitu 0,200 dan kelas kontrol nilai $p$-value $>$ yaitu 0,90 (taraf signifikansi $=0,05)$. Kriteria pengujiannya adalah data berdistribusi normal jika $p$-value $>0,05$. Sehingga dapat disimpulkan bahwa untuk kelas eksperimen dan kelas kontrol termasuk kategori normal. Postest untuk kelas eksperimen dan kelas kontrol menunjukkan nilai $p$ value > yaitu 0,200. Prestasi untuk kelas eksperimen dan kelas kontrol menunjukkan p-value > yaitu 0,90. Hal postest untuk kelas eksperimen dan kelas kontrol termasuk kategori normal.

2) Uji Homogenitas

Berdasarkan test of homogeneity of variance diperoleh nilai probabilitas (signifikansi) adalah 289 > 0,05 maka dapat 
disimpulkan bahwa kedua varian sama (varian kelompok eksperimen dan kelompok kontrol sama).

3) Pengujian Hipotesis Penelitian

Berdasarkan hasil uji ANOVA diperoleh t hitung $>$ t tabel $(1,354>1,68)$, maka $\mathrm{H}_{\mathrm{o}}$ ditolak. Hal ini berarti bahwa hasil belajar matematika siswa yang diajar dengan metode penemuan terbimbing setting kooperatif lebih baik dibandingkan dengan hasil belajar siswa yang diajar dengan metode konvensional.

Analisis data untuk hasil observasi aktivitas siswa selam proses pembelajaran dengan menggunakan metode penemuan terbimbing setting kooperatif disajikan Tabel 7 dan Tabel 8.

Tabel 7.

Hasil Observasi Aktivitas Siswa dengan Metode

Penemuan Terbimbing Setting Kooperatif dan Metode Konvensional

\begin{tabular}{lcc|}
\hline \multicolumn{1}{c}{ Aspek yang Dinilai } & Ekperimen & Kontrol \\
\hline $\begin{array}{l}\text { Siswa yang Hadir pada } \\
\text { saat pembelajaran }\end{array}$ & 96 & 94 \\
\begin{tabular}{|l} 
Siswa yang \\
mendengarkan/ \\
memperhatikan \\
penjelasan guru pada \\
saat PBM
\end{tabular} & 79 & 82 \\
\hline $\begin{array}{l}\text { Siswa yang Meminta } \\
\text { bimbingan guru dalam } \\
\text { menyelesaikan LKS }\end{array}$ & 18 & 12 \\
\hline $\begin{array}{l}\text { Siswa yang } \\
\text { membimbing teman } \\
\text { yang belum mengerti }\end{array}$ & 91 & 16 \\
\hline $\begin{array}{l}\text { Siswa yang } \\
\text { mempresentasikan } \\
\text { hasil diskusi di depan } \\
\text { kelas }\end{array}$ & 93 & 28 \\
\hline $\begin{array}{l}\text { Siswa yang aktif } \\
\text { menjawab pertanyaan } \\
\text { mencapai }\end{array}$ & 93 & \\
\hline $\begin{array}{l}\text { Siswa yang membuat } \\
\text { rangkuman/ }\end{array}$ & & \\
\hline
\end{tabular}

$\begin{aligned} & \text { menyimpulkan materi } \\
& \text { pelajaran }\end{aligned}$
\begin{tabular}{|l|cc|}
\hline Jumlah & 448 & 329 \\
\hline Rata-Rata & 64 & 47 \\
\hline
\end{tabular}

Berdasarkan data dari Tabel 7 dapat disimpulkan bahwa rata-rata aktivitas siswa yang diajar melalui metode penemuan terbimbing setting kooperatif mencapai 64\% dan berada pada kategori aktif sedangkan yang menggunakan metode konvensional hanya $47 \%$.

Hasil analisis data untuk mengetahui respon siswa terhadap metode yang digunakan di kelas dapat dilihat pada Tabel 8.

Tabel 8.

Hasil Angket Respon siswa yang diajar dengan Metode penemuan terbimbing setting Kooperatif dan metode konvensional

\begin{tabular}{lcc}
\hline \multicolumn{1}{c}{ Aspek yang Dinilai } & Ekperimen & Kontrol \\
\hline $\begin{array}{l}\text { Siswa yang } \\
\text { memperhatikan guru }\end{array}$ & 100 & 100 \\
ketika menerangkan & & \\
pelajaran matematika & & \\
\hline $\begin{array}{l}\text { Siswa yang menyukai } \\
\text { cara mengajar yang } \\
\text { diterapkan guru dalam } \\
\text { proses pembelajaran } \\
\text { dengan menggunakan } \\
\text { pembelajaran } \\
\text { matematika }\end{array}$ & & \\
\hline $\begin{array}{l}\text { Siswa yang leluasa } \\
\text { menyampaikan gagasan }\end{array}$ & & \\
atau pendapat \\
mengenai mengenai \\
materi pelajaran \\
matematika
\end{tabular}




\begin{tabular}{|c|c|c|}
\hline Aspek yang Dinilai & Ekperimen & Kontrol \\
\hline $\begin{array}{l}\text { Siswa yang } \\
\text { mendiskusikan } \\
\text { pelajaran matematika } \\
\text { dengan temannya }\end{array}$ & 87 & 28 \\
\hline $\begin{array}{l}\text { Siswa yang dapat } \\
\text { mengerjakan LKS yang } \\
\text { diberikan oleh guru } \\
\text { selama pembelajaran }\end{array}$ & 60 & 60 \\
\hline $\begin{array}{l}\text { Siswa yang merasa } \\
\text { semangat belajarnya } \\
\text { bertambah dengan } \\
\text { metode yang digunakan }\end{array}$ & 72 & 69 \\
\hline Jumlah & 571 & 425 \\
\hline Rata-Rata & 71,38 & 53,13 \\
\hline
\end{tabular}

Berdasarkan angket respon siswa pada tabel 8 bahwa sebesar 71,38\% menanggapi secara positif metode penemuan terbimbing. Sedangkan unutk metode konvensional juga memperoleh respon yang positif sebesar 53,13\%.

Hasil Obeservasi keterlaksanaan pembelajaran yang didasarkan pada Rencana Pelaksanaan Pembelajaran yang digunakan oleh guru pada metode penemuan terbimbing setting koopertif mencapai 3,16 dan berada pada kategori baik.

\section{B. Pembahasan}

Hasil analisis deskriptif menunjukkan bahwa hasil belajar matematika siswa berada pada kategori sedang dari 25 responden untuk kelompok eksperimen terdapat $14 \%$ siswa yang memiliki skor hasil belajar sedang, 28\% siswa yang memiliki skor hasil belajar yang tergolong tinggi dan $8 \%$ yang memiliki skor hasil belajar sangat tinggi, sedangkan untuk kelompok kontrol dari 25 responden terdapat 52\% siswa yang memiliki skor sedang, 8\% siswa yang memiliki skor hasil belajar yang tergolong tinggi dan $8 \%$ yang tergolong sangat tinggi. Hal ini dapat menunjukkan bahwa metode penemuan terbimbing setting kooperatif dapat meningkatkan hasil belajar siswa. Hasil penelitian ini pun didukung dari hasil penelitian yang dilakukan oleh (Nurcahyo, Agung S, \& Djono, 2018) yang menunjukkan bahwa pembelajaran dengan metode penemuan berbasis pendekatan ilmiah dapat memotivasi siswa untuk memecahkan masalah secara aktif dan mampu meningkatkan keterampilan berpikir kritis siswa sehingga siswa dapat membentuk pemikiran ilmiah termasuk mengamati, bertanya menalar, berusaha dan bekerjasama sehingga dapat berpengaruh pada hasil belajar siswa.

Dari hasil analisis data yang ditunjukkan pula bahwa nilai-rata-rata untuk kelompok yang menggunakan metode penemuan terbimbing setting kooperatif adalah 78 berada pada kategori sedang dan nilai ratarata untuk kelompok yang menggunakan metode konvensional adalah 68.44 berada pada kategori sedang, siswa yang memiliki skor tes hasil belajar matematika yang tergolong sangat tinggi untuk kelompok yang diajar dengan metode penemuan terbimbing setting kooperatif ialah 8\% dan $8 \%$ untuk kelompok yang diajar dengan metode konvensional, untuk kelompok yang diajar dengan metode penemuan terbimbing setting kooperatif yang tergolong tinggi ialah 28\% dan $8 \%$ untuk kelompok yang diajar dengan metode 
konvensional, dan untuk yang berada pada kategori sedang ialah 44\% untuk kelompok yang diajar dengan metode penemuan terbimbing setting kooperatif dan 52\% untuk kelompok yang diajar dengan metode konvensional dan untuk yang berada pada kategori rendah ialah 16\% untuk yang diajar dengan metode penemuan terbimbing setting kooperatif dan 28\% untuk diajar dengan metode konvensional. Dari uraian di atas terlihat bahwa hasil belajar matematika siswa kelas VIII SMP Negeri 21 Makassar yang diajar dengan metode penemuan terbimbing setting kooperatif lebih baik dibandingkan dengan hasil belajar matematika siswa yang diajar dengan metode konvensional, ini ditunjukkan oleh skor rata-rata oleh kedua perlakuan. Hasil pengamatan dengan menggunakan lembar observasi siswa, terlihat bahwa aktivitas siswa terhadap pembelajaran dengan menggunakan metode penemuan terbimbing setting kooperatif lebih aktif dari pada dengan menggunakan metode konvensional. Hal ini ditunjukkan oleh persentase setiap item untuk siswa yang diajarkan dengan menggunakan metode penemuan terbimbing setting kooperatif lebih tinggi daripada dengan menggunakan metode konvensional. Hal ini sejalan dengan hasil penelitian yang telah dilakukan oleh (Mawaddah \& Maryanti, 2016) menunjukkan bahwa kemampuan pemahaman konsep siswa terhadap matematika melalui metode penemuan terbimbing berada pada kategori baik dan siswa memberikan respon positif terhadap model pembelajaran penemuan terbimbing. Selain itu menurut hasil penelitian yang dilakukan oleh (Hermawan \& Hidayat, 2018) menunjukkan bahwa Pencapaian kemampuan penalaran matematik siswa SMP melalui pendekatan penemuan terbimbing lebih baik daripada pembelajaran biasa. Berdasarkan kenyataan perbandingan hasil analisis persentase per aspek dari angket siswa nampak bahwa siswa yang merespon secara positif penerapan metode penemuan terbimbing setting kooperatif diterapkan dalam pembelajaran matematika terutama pada pokok bahasan Fungsi adalah 73\%. Hal ini berarti bahwa pembelajaran dengan penerapan metode penemuan terbimbing setting kooperatif lebih direspon secara positif oleh siswa dibanding metode konvensional. Sedangkan hasil analisis statistik inferensial menunjukkan bahwa hipotesis penelitian diterima atau hasil belajar siswa kelas VIII SMP Negeri 21 Makassar dalam pembelajaran matematika yang diajar dengan metode penemuan terbimbing setting kooperatif lebih baik dibandingkan dengan hasil belajar siswa yang diajar dengan metode konvensional. Adanya perbedaan tingkat kemampuan siswa atau hasil belajar siswa untuk kedua kelompok tersebut menurut pengamatan penulis pada sampel yang diteliti disebabkan oleh faktor keterlibatan siswa secara aktif dalam proses belajar mengajar, serta pemilihan metode mengajar yang menuntut siswa 
aktif dalam belajar. Dari hasil analisis yang diperoleh, cukup mendukung teori yang telah dikemukakan pada kajian pustaka. Bila ditinjau dari keterlibatan siswa dalam proses belajar mengajar, pada saat eksperimen, ternyata kelompok yang menggunakan metode penemuan terbimbing setting kooperatif menampakkan minat yang tinggi, lebih bergairah dalam belajar, dan siswa dapat belajar secara aktif. Menurut hasil penelitian yang dilakukan oleh (Febriana, Haryono, \& Yusri, 2017) bahwa metode pembelajaran berbasis penemuan dapat meningkatkan aktivitas positif siswa dan menekan atau menurunkan aktivitas negative siswa di kelas. Selain itu dengan menerapkan metode penemuan terbimbing setting kooperatif siswa dapat meningkatkan keterampilannya dalam memecahkan masalah, terutama bagi siswa yang memiliki kemampuan rendah, dan membuat siswa senang belajar matematika.

\section{Penutup}

Kesimpulan dari penelitian ini metode penemuan terbimbing setting kooperatif efektif diterapkan pada pembelajaran matematika siswa kelas VIII SMP Negeri 21 Makassar. Oleh karena itu hendaknya guru mampu memilih metode pembelajaran yang tepat untuk diterapkan yang disesuaikan dengan kondisi siswa di kelas sehingga dapat menciptakan suasana belajar mengajar yang efektif agar dapat menunjang hasil belajar siswa nantinya.

\section{DAfTAR PUstaka}

Afriansyah, E. A. (2014). Addition and Substraction Numbers up to 10 through PMRI for SD/MI Level Students. International Postgraduate Colloqium of Research in Education 3rd IPCORE.

Afriansyah, E. A., Herman, T., Turmudi, T., \& Dahlan, J. A. (2020). Mendesain Soal Berbasis Masalah untuk Kemampuan Berpikir Kritis Matematis Calon Guru. Mosharafa: Jurnal Pendidikan Matematika, 9(2), 239-250.

Alam, Z. I., \& Razak, F. (2018). Pengembangan Lembar Kegiatan Siswa Berbasis Metode Penemuan Terbimbing Untuk Pembelajaran Matematika Pada Siswa Kelas XII SMA NEGERI 1 SEGERI. Mosharafa: Jurnal Pendidikan Matematika, 7(1), 1-12.

Ariandi, Y. (2016). Analisis Kemampuan Pemecahan Masalah Berdasarkan Aktivitas Belajar pada Model Pembelajaran PBL. PRISMA, Prosiding Seminar Nasional Matematika, $X(1996)$, 579-585.

Febriana, R., Haryono, Y., \& Yusri, R. (2017). Effectiveness of Discovery LearningBased Transformation Geometry Module. Journal of Physics: Conference Series, 895(1), 1-5.

Gillies, R. M. (2016). Cooperative learning: Review of research and practice. Australian Journal of Teacher Education, 41(3), 39-54.

Hermawan, A. S., \& Hidayat, W. (2018). Meningkatkan kemampuan Penalaran Matematik Siswa SMP Melalui Pendekatan Penemuan Terbimbing. JPMI (Jurnal Pembelajaran Matematika Inovatif), 1(1), 7-12.

Idzhar, A. (2016). Peranan guru dalam 
meningkatkan motivasi belajar siswa. Jurnal Kependidikan, 2(2), 221-228.

Jumhariyani. (2016). Pengaruh Metode Penemuan Terbimbing Dan Kemampuan Berpikir Kritis Terhadap Kemampuan Matematika Siswa Jumhariyani Matematika memegang peranan penting. Jurnal Pendidikan Dasar, 7(1), 62-73.

Karlina, E., \& Rasam, F. (2020). Penerapan Metode Pembelajaran Team Teaching Dalam Upaya Meningkatkan Hasil Belajar Mata Kuliah Matematika Ekonomi Di Unindra. Research and Development Journal of Education, 6(2), 65-73.

Mawaddah, S., \& Maryanti, R. (2016). Kemampuan Pemahaman Konsep Matematis Siswa SMP dalam Pembelajaran Menggunakan Model Penemuan Terbimbing (Discovery Learning). EDU-MAT: Jurnal Pendidikan Matematika, 4(1), 76-85.

Nurcahyo, E., Agung S, L., \& Djono, D. (2018). The Implementation of Discovery Learning Model with Scientific Learning Approach to Improve Students' Critical Thinking in Learning History. International Journal of Multicultural and Multireligious Understanding, 5(3), 106-112.

Pitriani, R., \& Afriansyah, E. A. (2016). Persepsi dalam pembelajaran pendekatan keterampilan proses terhadap kemampuan koneksi matematis siswa (Studi penelitian di SMP Negeri 1 Wanraja). Jurnal Gantang, 1(2), 15-24.

Purwananti, Y. S. (2016). Peningkatan Kualitas Pendidikan Sebagai Pencetak Sumber Daya Manusia Handal. Proceedings International Seminar FoE
(Faculty of Education), 220-229.

Puspitaningdyah, D. ., \& Purwanti, E. (2018). Pengaruh Keterampilan Mengelola Kelas dan Keaktifan Belajar terhadap Hasil Belajar IPS SD. Joyful Learning Journal, 7(1), 39-47.

Puspitasari, N. (2018). Kemampuan Mengajukan Masalah Direlasikan dengan Kemampuan Berpikir Logis Matematik. Mosharafa: Jurnal Pendidikan Matematika, 7(1), 121132.

Putri, F. E., Amelia, F., \& Gusmania, Y. (2019). Hubungan Antara Gaya Belajar dan Keaktifan Belajar Matematika Terhadap Hasil Belajar Siswa. Edumatika: Jurnal Riset Pendidikan Matematika, 2(2), 83-88.

Riyadi, A., Mulyono, D., \& Purwasi, L. A. (2018). Penerapan Metode Penemuan Terbimbing Pada Pembelajaran Matematika Siswa SMP. Journal of Education and Instruction (JOEAI), 1(1), 51-58.

Rochani, S. (2016). Keefektifan pembelajaran matematika berbasis masalah dan penemuan terbimbing ditinjau dari hasil belajar kognitif kemampuan berpikir kreatif. Jurnal Riset Pendidikan Matematika, 3(2), 273.

Saridewi, N., Suryadi, J., \& Hikmah, N. (2017). The Implementation of Discovery Learning Method to Increase Learning Outcomes and Motivation of Student in Senior High School. Jurnal Penelitian Dan Pembelajaran IPA, 3(2), 124-133.

Sejati, E. O. W., \& Widjajanti, D. B. (2019). Pembelajaran kooperatif dalam pendekatan penemuan terbimbing ditinjau dari prestasi belajar, 
kemampuan berpikir kritis, dan kepercayaan diri. Pythagoras: Jurnal Pendidikan Matematika, 14(2), 150162.

Sholihah, D. A., \& Mahmudi, A. (2015). Keefektifan Experiential Learning Pembelajaran Matematika Mts Materi Bangun Ruang Sisi Datar. Jurnal Riset Pendidikan Matematika, 2(2), 175185.

Siregar, I. (2016). Masalah Pembelajaran Pembuktian Matematika bagi Mahasiswa di Indonesia. Mosharafa: Jurnal Pendidikan Matematika, 5(3), 315-324.

Siregar, I., \& Sari, V. T. A. (2020). Strategi Motivasi Green's, Gaya Baru Pembelajaran Matematika pada Siswa Kemampuan Rendah di Indonesia. Mosharafa: Jurnal Pendidikan Matematika,9(3), 383394.

Suharyono, E., \& Rosnawati, R. (2020). Analisis Buku Teks Pelajaran Matematika SMP ditinjau dari Literasi Matematika. Mosharafa: Jurnal Pendidikan Matematika,9(3), 451462.

Tahir, T., \& Kurniawan, P. (2020). Penerapan Model Pembelajaran Penemuan Terbimbing Terhadap Peningkatan Kemampuan Pemecahan Masalah Matematis Mahasiswa. AKSIOMA: Jurnal Program Studi Pendidikan Matematika, 9(4), 10591066.

Warti, E. (2018). Pengaruh Motivasi Belajar Siswa terhadap Hasil Belajar Matematika Siswa di SD Angkasa 10 Halim Perdana Kusuma Jakarta Timur. Mosharafa: Jurnal Pendidikan Matematika, 5(2), 177-185.
Wibowo, N. (2016). Pembelajaran Berdasarkan Gaya Belajar Di Smk Negeri 1 Saptosari. Jurnal Electronics, Informatics, and Vocational Education (ELINVO), 1(2), 128-139.

Widiawati, N., \& Sofyan, D. (2013). Perbandingan Prestasi Belajar Matematika Siswa antara yang Mendapatkan Metode Kumon dan Metode Konvensional. Mosharafa: Jurnal Pendidikan Matematika,2(2), 99-110.

\section{Riwayat Hidup PenUlis}

Nur Qalbi Tayibu, M.Pd.

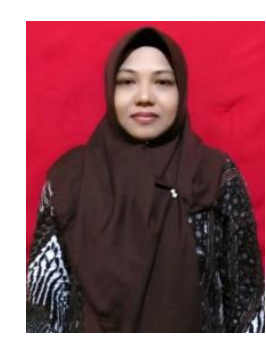

Lahir di Bulukumba, 16 Februari. Staf pengajar di Institut Sains dan Teknologi Pembangunan Indonesia (IST-PI) Makassar. Studi S1 Pendidikan Matematika Universitas Muhammdiyah Makassar lulus tahun 2013; S2 Pendidikan Matematika Universitas Negeri Makassar lulus tahun 2015

\section{Andi Nurul Faizah, M.Pd.}

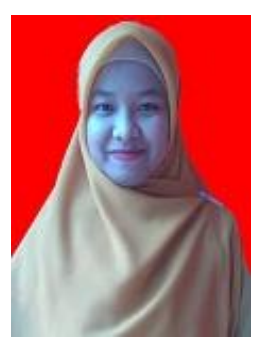

Lahir di Bulukumba, 16 Februari. Staf pengajar di STMIK Bina Adinata. Studi S1 Pendidikan Matematika Universitas Muhammdiyah Makassar lulus tahun 2013; S2 Pendidikan Matematika Universitas Negeri Makassar lulus tahun 2015 